\title{
Kondisi Padang Lamun di Perairan Teluk Awur Jepara Terkait dengan Parameter Lingkungan Perairan dan Keberadaan Sampah Makro Plastik
}

\author{
Hendra Kurniawan*, Bambang Yulianto, Ita Riniatsih \\ Departemen IImu Kelautan, Fakultas Perikanan dan IImu Kelautan, Universitas Diponegoro \\ JI. Prof. H. Soedarto S.H, Tembalang, Semarang, Jawa Tengah 50275 Indonesia \\ ${ }^{*}$ Corresponding author, e-mail : kurniwanhendra216@gmail.com
}

\begin{abstract}
ABSTRAK: Ekosistem padang lamun merupakan salah satu ekosistem di wilayah pesisir yang mempunyai peranan yang penting untuk menjaga kelestarian dan keanekaragaman organisme laut. Kondisi parameter perairan pesisir merupakan faktor penting terhadap kondisi padang lamun yang meliputi kecerahan perairan, pasang surut, arus, gelombang, suhu, salinitas, DO, kadar BOT dan pencemaran. Penelitian ini bertujuan untuk melihat pengaruh kondisi oseanografi dan sampah makro plastik terhadap kondisi padang lamun di perairan Teluk Awur Jepara yang dilakukan pada 3 stasiun pengamatan. Hasil penelitian menunjukkan bahwa bahwa tipe pasang surut di lokasi pengamatan adalah mixed tide prevailing semi durnal. Kisaran data kecerahan 30-40 cm, kisaran kecepatan arus antara $0,109-0,0154 \mathrm{~m} /$ det, tinggi gelombang $0,5-126 \mathrm{~cm}$, suhu $28-30{ }^{\circ} \mathrm{c}$, salinitas 34-35\%, kisaran kadar DO 4,2-4,9 ppm, dan kisaran kadar BOT 9,9-11,9 mg/liter. Kisaran berat sampah yang di temukan $0,08 \mathrm{~kg}-1,8 \mathrm{~kg}$ di seluruh stasiun. Kisaran prosentase penutupan lamun seluruh stasiun 14,678\% - 20,706\%, hal ini menunjukan bahwa kondisi padang lamun di perairan Teluk Awur dalam kondisi tidak sehat (>25\%).
\end{abstract}

Kata Kunci: Kondisi oseanografi; Padang lamun; Perairan Teluk Awur

\section{The condition of the Seagrass beds in the waters of Teluk Awur Jepara is related to the parameters of the water environment and the presence of plastic macro waste}

\begin{abstract}
Seagrass ecosystem is one of the ecosystems in coastal areas that has an important role to maintain the sustainability and diversity of marine organisms. The condition of coastal water parameters is an important factor for seagrass conditions including waters brightness, tides, currents, waves, temperature, salinity, DO, BOT levels and pollution. This study aims to look at the effect of oceanographic conditions and macro plastic waste on seagrass conditions in the waters of Teluk Awur Jepara conducted at 3 observation stations. The results showed that the tidal type at the observation site was mixed tide prevailing semi durnal. Brightness data range is $30-40 \mathrm{~cm}$, current speed range is between 0.109-0.0154 m/ sec, wave height is $0.5-126 \mathrm{~cm}$, temperature is $28-30^{\circ} \mathrm{C}$, salinity is 34-35\%, DO content range is 44,2-4,9ppm, and the range of BOT levels $9.9-11.9 \mathrm{mg} /$ liter. The range of waste weight found was $0.08 \mathrm{~kg}-1.8 \mathrm{~kg}$ at all stations. The range of seagrass closure percentage for all stations is $14.678 \%-20.706 \%$, this shows that the condition of seagrass in waters of Teluk Awur Jepara is in an unhealthy condition (>25\%).
\end{abstract}

Keywords: Oceanographic condition; Seagrass; Teluk Awur Water

\section{PENDAHULUAN}

Ekosistem padang lamun merupakan salah satu ekosistem di wilayah pesisir yang mempunyai produktivitas primer yang relatif tinggi dan mempunyai peranan yang penting untuk menjaga kelestarian dan keanekaragaman orgnisme laut (Riniatsih, 2016). Padang lamun mempunyai fungsi sebagai daerah pemijahan, daerah mencari makan dan daerah asuhan bagi organisme laut muda yang biasanya memanfaatkan daerah pasang surut dan padang lamun sebagai tempat berlindung dan mencari makan pada masa stadia larva (Riniatsih et al., 2007). Padang lamun mempunyai peranan penting dalam menjaga keseimbangan ekosistem di perairan laut. Salah satu fungsi fisik padang lamun adalah sebagai pendaur ulang zat hara di perairan. Aktivitas mikroorganisme 
pengurai mengembalikan bahan anorganik ke perairan melalui proses dekomposisi dari bahan organik atau jaringan hidup yang berupa detritus serasah lamun. Lingkungan yang sangat mendukung di perairan pesisir menjadikan lamun dapat hidup dan berkembang secara optimal. Namun kondisi ini juga menjadi ancaman jika nutrien dalam konsentrasi yang terlalu tinggi. Akibatnya terjadi pengayaan nutrien (eutrophycation) yang dapat menyebabkan meledaknya populasi alga (algae bloom) (Rustam et al., 2015).

Kondisi habitat padang lamun sangat dipengaruhi oleh beberapa parameter hidro- oseanografi perairan di sekitar habitat hidup lamun. Parameter perairan yang berpengaruh terhadap pertumbuhan lamun adalah kondisi fisika, kimia dan biologi perairan. Kondisi oseanografi akan sangat mempengaruhi kondisi suatu perairan yang ada. Arus berperan mentransport nutiren yang ada di perairan lalu nutrient tersebut akan di manfaatkan oleh biota yang ada pada perairan tersebut (Manson, 1981). Demikian juga dengan aspek lain seperti pasang surut yang terjadi pada suatu perairan akan mempengaruhi biota-biota yang ada pada suatu perairan tersebut. Suhu dan salinitas yang optimal akan membantu mempercepat proses pertumbuhan dan perkembangan biota-biota yang ada pada perairan tersebut. Bahan Organik Terlarut menggambarkan kandungan keseluruhan bahan organik suatu perairan yang terdiri dari bahan organik terlarut atau tersuspensi.

Kecepatan arus di padang lamun mempunyai pengaruh yang sangat nyata. Produktivitas padang lamun tampak dari pengaruh keadaan kecepatan arus perairan, dimana mempunyai kemampuan maksimum menghasilkan "standing crop" pada saat kecepatan arus sekitar 0,5 m/det (Dahuri et al., 2001).

Perairan Teluk Awur sebagai perairan pesisir memiliki nilai keanekaragaman jenis lamun yang relative tinggi. Namun seiring berjalannya waktu dan perubahan iklim yang terjadi di dunia dapat mempengaruhi kondisi padang lamun. Berubah- ubahnya kondisi cuaca yang tidak menentu mengakibatkan perubahan kondisi oseanografi yang ada di perairan Teluk Awur dan berdampak terhadap kondisi padang lamun. Untuk itu perlu dilakukan penelitian dengan tujuan untuk: mengetahui seberapa besar pengaruh kondisi oseanografi terhadap kondisi padang lamun yang ada di perairan Teluk Awur Jepara.

Banyak ekosisten perairan, seperti ekosistem mangrove, lamun dan terumbu karang, mengalami kerusakan akibat pencemaran polusi yang berasal dari daratan. Dampak kontaminasi yang disebabkan oleh manusia terjadi secara lokal maupun global di ekosistem mangrove, pantai dan lautan terbuka (Jambeck et al., 2015). Pencemaran yang terjadi dalam bentuk limbah padat maupun cair. Beberapa contoh dari limbah padat yang mencemari pantai, laut dangkal hingga laut terbuka yaitu sampah plastik, logam, kertas, dan kaca. Diperkirakan sampah plastik mencemari dalam bentuk potongan makro maupun mikro dengan jumlah kisaran 7.000 - 35.000 ton (Jambeck et al., 2015).

\section{MATERI DAN METODE}

Materi yang digunakan dalam penelitian ini adalah kondisi ekosistem padang lamun, yang berupa data prosentase penutupan lamun di perairan Teluk Awur Jepara. Data prosentase penutupan padang lamun dihitung secara langsung di lokasi penelitian dengan mempergunakan metode LIPI (Rahmawati et al., 2014).

Parameter perairan yang digunakan dalam penelitian ini adalah parameter hasil pengukuran dari sampel air laut yang diambil pada beberapa lokasi penelitian di padang lamun perairan Teluk Awur. Pada penelitian ini parameter yang diamati adalah kandungan BOT. Selain materi tersebut di atas, juga dilakukan pengambilan data untuk mengetahui beberapa parameter hidrooseanografi perairan, yang antara lain meliputi suhu perairan, salinitas, kecepatan arus, oksigen terlarut, pasang surut dan tinggi gelombang.

Metode yang digunakan dalam penelitian ini adalah studi kasus dan cara pengumpulan data dengan menggunakan sample survey metode, yaitu metode pengumpulan data dengan cara pengamatan terhadap sebagian populasi yang hasilnya diharapkan dapat menggambarkan sifat populasi dari obyek penelitian, sehingga dapat digunakan untuk menggambarkan suatu pupolasi di suatu habitat pada waktu tertentu (Rahmawati et al., 2014).

Lokasi penelitian ditentukan secara Purposif, yaitu penentuan titik sampling dengan terlebih dahulu melalui beberapa pertimbangan. Pertimbangan penentuan lokasi didasarkan pada distribusi 
jenis lamun. Selain melihat dari distribusi jenis lamun pertimbangan lain didasarkan oleh aktivitas masyarakat pesisir yang terjadi di setiap lokasi penelitian yang akan dipilih. Lokasi penelitian meliputi perairan padang lamun di Teluk Awur, Jepara yang terbagi menjadi tiga stasiun. Masing- masing stasiun dibagi menjadi tiga sub stasiun (Dermaga sebagai Stasiun I: I.1, I.2 dan I.3; daerah sekitar lapangan sebagai Stasiun II: II.1., II.2 dan II.3; lokasi belakang asrama mahasiswa sebagai Stasiun III yang terbagi menjadi; III.1, III.2 dan III.3). Pengambilan sampel lapangan dilakukan selama bulan November 2019, dengan pengulangan 3 kali ulangan untuk setiap sub stasiunnya, dengan selang waktu pengambilan 2 minggu.

Penghitungan prosentase penutupan lamun dilakukan dengan metoda line transect dengan pendekatan estimasi dari metode LIPI (Rahmawati et al., 2014). Pada setiap kuadran transek juga dilakukan pengambilan data ukuran daun lamun setiap spesies yang di temukan. Pengambilan sampel air laut menggunakan botol sampel di setiap substasiun. Selama pengambilan sampel juga dilakukan pengukuran parameter hidro-oseanografi secara in situ (suhu, salinitas, kecepatan arus, pasang surut, dan gelombang). Pengukuran pasang surut dilakukan dengan waktu 36 jam untuk mengetahui tipe pasang surut yang ada dan untuk data oseanografi yang lain dilakukan di setiap stasiun.

Tabel 1. Titik Koordinat Pada Stasiun di Lokasi Penelitian

\begin{tabular}{|c|c|c|c|}
\hline \multirow{2}{*}{ Stasiun } & \multirow{2}{*}{ Lokasi Penelitian } & \multicolumn{2}{|c|}{ Koordinat } \\
\hline & & $S$ & $E$ \\
\hline \multirow[t]{3}{*}{ Stasiun 1} & Line 1 & $6^{\circ} 37^{\prime} 01.09 " S$ & $110^{\circ} 38^{\prime} 25.5^{\prime \prime E}$ \\
\hline & Line 2 & $6^{\circ} 37^{\prime} 01.07 " \mathrm{~S}$ & $110^{\circ} 38^{\prime} 23.8 " E$ \\
\hline & Line 3 & $06^{0} 37^{\prime} 01.8 " S$ & $110^{\circ} 38^{\prime} 21.6 " \mathrm{E}$ \\
\hline \multirow[t]{3}{*}{ Stasiun 2} & Line 1 & $6^{\circ} 37^{\prime} 12.0^{\prime \prime S}$ & $110^{\circ} 38^{\prime} 13.9 " \mathrm{E}$ \\
\hline & Line 2 & $6^{\circ} 37^{\prime} 13.9 " S$ & $110^{\circ} 38^{\prime} 14.4 " \mathrm{E}$ \\
\hline & Line 3 & $6^{\circ} 37^{\prime} 15.2^{\prime \prime S}$ & $110^{\circ} 38^{\prime} 13.8 " \mathrm{E}$ \\
\hline \multirow[t]{3}{*}{ Stasiun 3} & Line 1 & $6^{\circ} 37^{\prime} 28.5^{\prime \prime S}$ & $110^{\circ} 38^{\prime} 16.8^{\prime \prime E}$ \\
\hline & Line 2 & $6^{\circ} 37^{\prime} 30.0^{\prime \prime S}$ & $110^{\circ} 38^{\prime} 16.4^{\prime \prime E}$ \\
\hline & Line 3 & $6^{\circ} 37^{\prime} 17.4^{\prime \prime S}$ & $110^{\circ} 38^{\prime} 12.3 " \mathrm{E}$ \\
\hline
\end{tabular}
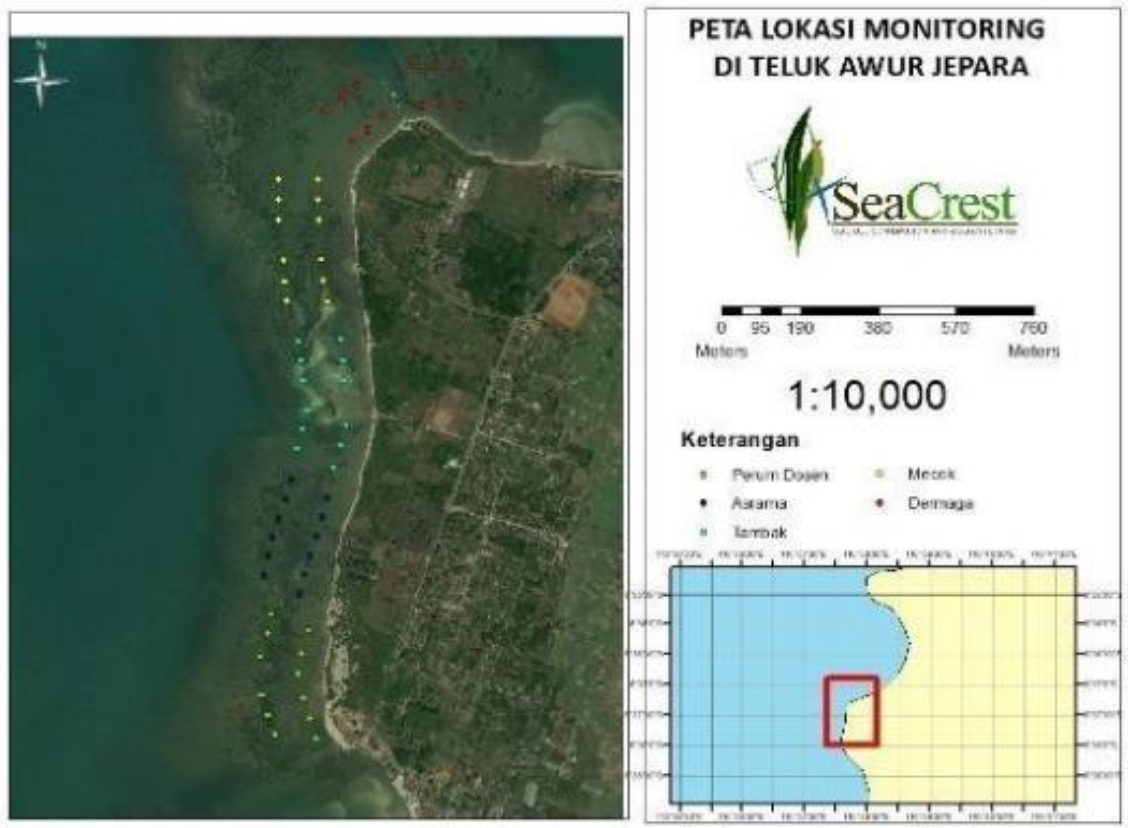

Gambar 1. Lokasi penelitian Teluk Awur Jepara

Keterangan: $\bullet=$ Perumahan dosen; $\bullet=$ Asrama; $\odot=$ Tambak; $\bigcirc=$ Mecok; $\bullet=$ Dermaga 
Data sampah makro plastik, di tiap titik pengamatan, di catat jumlah dan jenis sampah yang ditemukan. Transek dilakukan dengan berjalan dari tepi air laut ke arah daratan hingga 2 meter di belakang dimulainya deretan vegetasi yang berdekatan dengan garis pantai dan ini yang disebut sebagai panjang transek. Panjang transek ini kemudian dibagi menjadi 10 untuk menentukan interval (Schuyler et al., 2018). Sedangkan untuk lebar transek adalah 2 meter, 1 meter di sisi kiri dan 1 meter di sisi kanan. Metode ini dapat memberikan gambaran sebaran sampah laut di suatu wilayah pantai dengan cepat, tepat, dan pada satu lokasi survei hanya memerlukan $3-4$ orang surveyor metode ini disebut $C$-SIRO. Sampah yang ditemukan dikumpulkan dan dikelompokkan menurut jenisnya. Setelah itu dilakukan penghitungan ukuran luas sampah dan penimbangan untuk memperoleh data berat sampah (dalam $\mathrm{Kg}$ ).

\section{HASIL DAN PEMBAHASAN}

Hasil identifikasi jenis lamun yang ditemukan di lokasi penelitian adalah Enhalus acoroides, Thalassia hemprichii, Cymodocea serrulata, Cymodocea rotundata, dan Syringodium isoetifolium. Prosentase penutupan lamun selama penelitian menunjukkan bahwa penyebaran lamun terkait dengan sebaran jenis substrat dasar di lokasi penelitian disajikan pada Tabel 2.

Tabel 2. Rata-rata Prosentase Cover Jenis Lamun di perairan Teluk Awur (\%)

\begin{tabular}{|c|c|c|c|c|}
\hline \multirow{2}{*}{ No } & \multirow[b]{2}{*}{ Jenis Lamun } & \multicolumn{3}{|c|}{ Stasiun } \\
\hline & & I & II & III \\
\hline 1. & Thalassia hemprichii & 4,166 & 2,0833 & 22,727 \\
\hline 2. & Chymodocea rotundata & 8,712 & 14,394 & 7,197 \\
\hline 3. & Syringodium isotifolium & 0 & 1,3671 & 0 \\
\hline 4. & Enhalus acoroides & 1,7045 & 0,5681 & 0,946 \\
\hline
\end{tabular}

Rata-rata persentase tutupan lamun di Teluk Awur pada Stasiun 1 sebesar 14,583\%, Stasiun 2 sebesar 16,287\%, dan Stasiun 3 sebesar 31,25\%. Prosentase penutupan lamun yang terendah terdapat pada Stasiun 1. Hal ini diduga disebabkan karena Stasiun 1 berada di daerah dermaga kampus yang banyak terdapat aktivitas perahu sandar, aktivitas manusia seperti aktivitas nelayan yang memancing dan menginjak padang lamun yang ada disekitar, yang mengakibatkan kondisi padang lamun dilokasi tersebut masuk dalam kondisi tidak sehat. Kondisi prosentase penutupan lamun tertinggi terdapat pada Stasiun 3, lokasinya yang berdekatan dengan asrama mahasiswa. Aktivitas manusia disekitar lokasi Stasiun 3 sanat minim, diduga tidak adanya gangguan dari aktivitas manusia ini yang menyebabkan kondisi prosentase cover tutupan lamun di Stasiun 3 tinggi apa bila dibandingkan dengan Stasiun 1 dan 2. Berdasarkan data hasil penghitungann prosentase penutupan lamun, padang lamun di wilayah Teluk Awur Jepara dapat dikatagorikan dalam kondisi tidak sehat.

Hasil pengukuran morfometrik daun lamun di perairan Teluk Awur selama penelitian dapat dilihat pada Tabel 3. Sedangkan untuk ukuran morfometrik daun lamun di perairan Teluk Awur mempunyai ukuran lebih kecil apabila dibandingkan dengan hasil penelitian ukuran morfometrik daun lamun yang disampaikan oleh Waycot et al. (2004) di laut Indo-Pacifik Australia, dan EI Shaffai, (2011) di laut Merah. Panjang daun lamun di lokasi penelitian berkisar antara $30-45 \mathrm{~cm}$ dengan lebar dengan kisaran 1-2,5 cm, berbeda denga ukuran daun lamun yang ditemukan di Indo-Pacifik Australia, dengan lamun jenis Enhalus acoroides mempunyai daun yang panjang berkisar antara $30-200 \mathrm{~cm}$ dan lebar daun 1,2-2 cm. Untuk lamun jenis Syringodium isoetifolium di lokasi penelitian hanya ditemukan pada stasiun 2 dengan panjang 3-18 cm lebar 0, 05-0,3 cm. Berbeda dengan laut Indo-Pacific Australia daun Syringodium isoetifolium memilikii panjang dari daun bervariasi dari 5$50 \mathrm{~cm}$. Berbedanya morfometrik dari daun di daerah Australia dan laut Merah pada perairan Teluk Awur diduga karena kondisi perairan kedua lokasi yang berbeda.

Bentuk dari morofologi daun lamun tentunya akan sangat mempengaruhi kondisi perairan tempat padang lamun itu hidup. Menurut Tangke (2010), padang lamun berfungsi sebagai sebagai stabilisator perairan dengan fungsi sistem perakaran dan daunnya sebagai perangkap dan penstabil 
sedimen dasar sehingga perairan menjadi lebih baik. Daun lamun akan meredam arus yang ada pada suatu perairan lalu juga akan menghamat distribusi sedimen yang terjadi, seperti menempelnya sedimen-sedimen pada daun lamun atau mengendapkan sedimen di dasar perairan.

Selain itu daun lamun rentan terhadap gangguan yang diakibatkan kondisi sekitar. Gangguan kondisi sekitar yang dimaksud adalah patahnya daun lamun yang diakibatkan oleh gelombang dan arus pada lingkungan padang lamun ataupun akibat aktivitas masyarakat sekitar yang mengakibatkan daun lamun patah. Contoh dari aktivitas tersebut adalah lalu lintas kapal nelayan yang berlalu lalang di sekitar kawasan padang lamun. Hal demikian dapat mengurangi kemampuan fungsi daun lamun sebagai peredam arus dan ataupun sebagai perangkap sedimen yang akan berperan untuk menjaga kelangsungan padang lamun di perairan Teluk Awur.

Hasil pengukuran parameter hidro-oseanografi perairan menunjukkan bahwa kecepatan arus tertinggi terdapat pada Stasiun 2 yaitu $0,0198 \mathrm{~m} /$ det sedangkan kecepatan arus terendah terdapat pada Stasiun 3 yaitu 0,0109 m/det. Gelombang air laut terdapat pada setiap stasiun berkisar 0,08$11,59 \mathrm{~cm}$. Suhu pada setiap stasiun penelitian berkisar $28-30^{\circ} \mathrm{C}$. Nilai BOT pada Stasiun 1 sebesar 9,903 mg/L, Stasitun 2 sebesar 11,9 mg/L dan Stasiun 3 sebesar 11,9 mg/L. Kandungan oksigen terlarut tertinggi terdapat pada stasiun 3 sebesar $4,9 \mathrm{ppm}$ dan terendah terdapat pada Stasiun 1 sebesar 4,2 ppm (Tabel 4). Tipe pasang surut air laut di Teluk Awur tergolong pasang surut tipe mixed tide prevailing semi durnal, yaitu terjadi pasang surut terjadi dua kali dalam satu hari.

Hasil dari pengamatan dan analisis kondisi oseanografi yang dilakukan di perairan menunjukan bahwa kecepatan arus rata-rata yang ada di perairan Teluk Awur dikategorikan lambat. Menurut Mason (1981), kecepatan arus cepat berkisar 0,5-1 m/det dan lambat berkisar 0,01-0,25 $\mathrm{m} / \mathrm{s}$. Sehingga dapat dikatakan bahwa kecepatan arus pada lokasi penelitian termasuk dalam kategori lambat. Gelombang air laut terdapat pada setiap stasiun berkisar $0,08-11,59 \mathrm{~cm}$. Tinggi gelombang akan membantu transpor sampah ke perairan karena umumnya gelombang disebabkan oleh angin sehingga selalu menimbulkan ayunan air yang bergerak tanpa hentinya pada lapisan permukaan air laut dan jarang dalam keadaan sama sekali diam. Nikki (2009) menyatakan bahwa tinggi gelombang akan membantu proses masuknya nutrient yang dibutuhkan oleh padang lamun hidup.

Tabel 3. Data morfometrik daun lamun di perairan Teluk Awur (cm)

\begin{tabular}{lcrrr}
\hline \multirow{2}{*}{ Jenis Lamun } & \multirow{2}{*}{ Ukuran } & \multicolumn{3}{c}{ Stasiun } \\
\cline { 3 - 5 } Cymodocea rotundata & $\mathrm{P}$ & $3,2-14,8 \mathrm{~cm}$ & 2 & \multicolumn{1}{c}{3} \\
& $\mathrm{~L}$ & $0,3-0,6 \mathrm{~cm}$ & $0,5-1 \mathrm{~cm}$ & $3-14,2 \mathrm{~cm}$ \\
Thalassia hemprichii & $\mathrm{P}$ & $5,5-19 \mathrm{~cm}$ & $4-16 \mathrm{~cm}$ & $5,8-20 \mathrm{~cm}$ \\
& $\mathrm{~L}$ & $1-3 \mathrm{~cm}$ & $1-3 \mathrm{~cm}$ & $0,5-1,5 \mathrm{~cm}$ \\
Enhalus acoroides & $\mathrm{P}$ & $30-40 \mathrm{~cm}$ & $25-40 \mathrm{~cm}$ & $20-45 \mathrm{~cm}$ \\
& $\mathrm{~L}$ & $1-2,5 \mathrm{~cm}$ & $1-2 \mathrm{~cm}$ & $1-1,8 \mathrm{~cm}$ \\
Syringodium isoetifolium & $\mathrm{P}$ & 0 & $0,3-1,8 \mathrm{~cm}$ & 0 \\
& $\mathrm{D}$ & 0 & $0,05-0,3 \mathrm{~cm}$ & 0 \\
\hline
\end{tabular}

Tabel 4. Kisaran Parameter Oseanografi di Setiap Stasiun Pada Perairan Teluk Awur

\begin{tabular}{lrrr}
\hline \multirow{2}{*}{ Parameter Oseanografi } & \multicolumn{3}{c}{ Stasiun } \\
\cline { 2 - 4 } & \multicolumn{1}{c}{1} & \multicolumn{1}{c}{3} \\
\hline Kecepatan arus (m/det) & 0,0156 & 0,0198 & 0,0109 \\
Gelombang (cm) & 1,26 & 0,73 & 0,50 \\
Suhu $\left({ }^{\circ} \mathrm{c}\right)$ & 28 & 30 & 28 \\
Salinitas (\%o) & 34 & 35 & 35 \\
BOT (mg/liter) & 9,903 & 11,9 & 11,9 \\
DO (ppm) & 4,2 & 4,2 & 4,9 \\
Kecerahan (cm) & 30 & 35 & 40 \\
\hline
\end{tabular}


Menurut Patty (2013), menyatakan bahwa suhu perairan di kawasan padang lamun yang optimal untuk pertumbuhan lamun yaitu $28-32^{\circ} \mathrm{C}$. Bisa dikatakan bahwa suhu yang rata-rata yang adapada perairan Teluk Awur sudah berada pada kondisi optimum untuk pertumbuhan yang ada disana.

Kisaran nilai salinitas setiap stasiun berkisar 34-35\%. Nilai-nilai salinitas di perairan padang lamun termasuk kisaran yang cocok untuk kehidupan lamun dan biota yang ada di dalamnya. Pertumbuhan lamun membutuhkan salinitas optimum berkisar 24 - $35 \%$ (Satria dan Misbah, 2012).

Bahan organik adalah kumpulan beragam senyawa-senyawa organik kompleks yang sedang atau telah mengalami proses dekomposisi, baik berupa humus maupun senyawa-senyawa anorganik hasil mineralisasi, juga mikrobia heterotrofik dan ototrofik. BOT juga berasal dari daratan (serasah yang jatuh ke tanah, dsb), penguraian organisme yang mati oleh bakteri, dan hasil metabolisme fitoplankton dan tumbuhan laut (Baron et al., 2006) Kandungan BOT pada perairan penelitian berkisar antara 9,9-11,9 mg/L. Menurut Akib et al (2015), perairan dengan kandungan BOT di atas $26 \mathrm{mg} / \mathrm{L}$ tergolong subur. Sehingga, dapat dikatakan bahwa setiap stasiun pengamatan memiliki perairan yang kurang subur. Rendahnya kadungan BOT pada perairan Teluk Awur menyebabkan lamun yang ada disana akan mengalami kekurangan nutrien karena kurang suburnya perairan tersebut.

Rendahnya kadar BOT di perairan Teluk Awur mengakibatkan buruknya kondisi padang lamun yang ada disana. Pada Stasiun 1 memiliki kadar BOT terendah dan hal ini beriringan dengan rendahnya nilai persentase cover lamun yang ada pada stasiun 1. Hal ini membuktikan bahwa kadar BOT sangat mempengaruhi kondisi padang lamun disuatu perairan.

Kandungan oksigen terlarut tertinggi terdapat pada Stasiun 3 sebesar 4,9 ppm dan terendah terdapat pada Stasiun 1 dan 1 sebesar 4,2 ppm. Menurut Akib et al. (2015), kandungan oksigen \pm 6 ppm, dapat di golongkan dalam kondisi perairan yang baik. Jadi dapat dikatakan perairan Teluk Awur memiliki kondisi yang kurang baik.

Terkait dengan kecerahan perairan di lokasi penelitian, intensitas cahaya matahari yang dapat mencapai bagian dasar perairan (0,75-1,70 meter) mendukung pertumbuhan lamun. Lamun membutuhkan minimal $20 \%$ cahaya permukaan untuk bertahan hidup. Oleh karena itu stabilisasi sedimen memainkan peran penting untuk menjaga kondisi padang lamun tetap jernih. Kondisi sedimen disuatu perairan akan dipengaruhi oleh arus dan gelombang (Riniatsih et al., 2017). Sedimen juga dapat mempeharuhi tingkat kecerahan suatu perairan. Perairan Teluk Awur memiliki kisaran nilai kecerahan $30-40 \mathrm{~cm}$, penetrasi cahaya dan proses absorbsi tidak berjalan optimal. Menurut Suparjo (2009), nilai kecerahan yang baik untuk biota lebih besar dari $45 \mathrm{~cm}$.

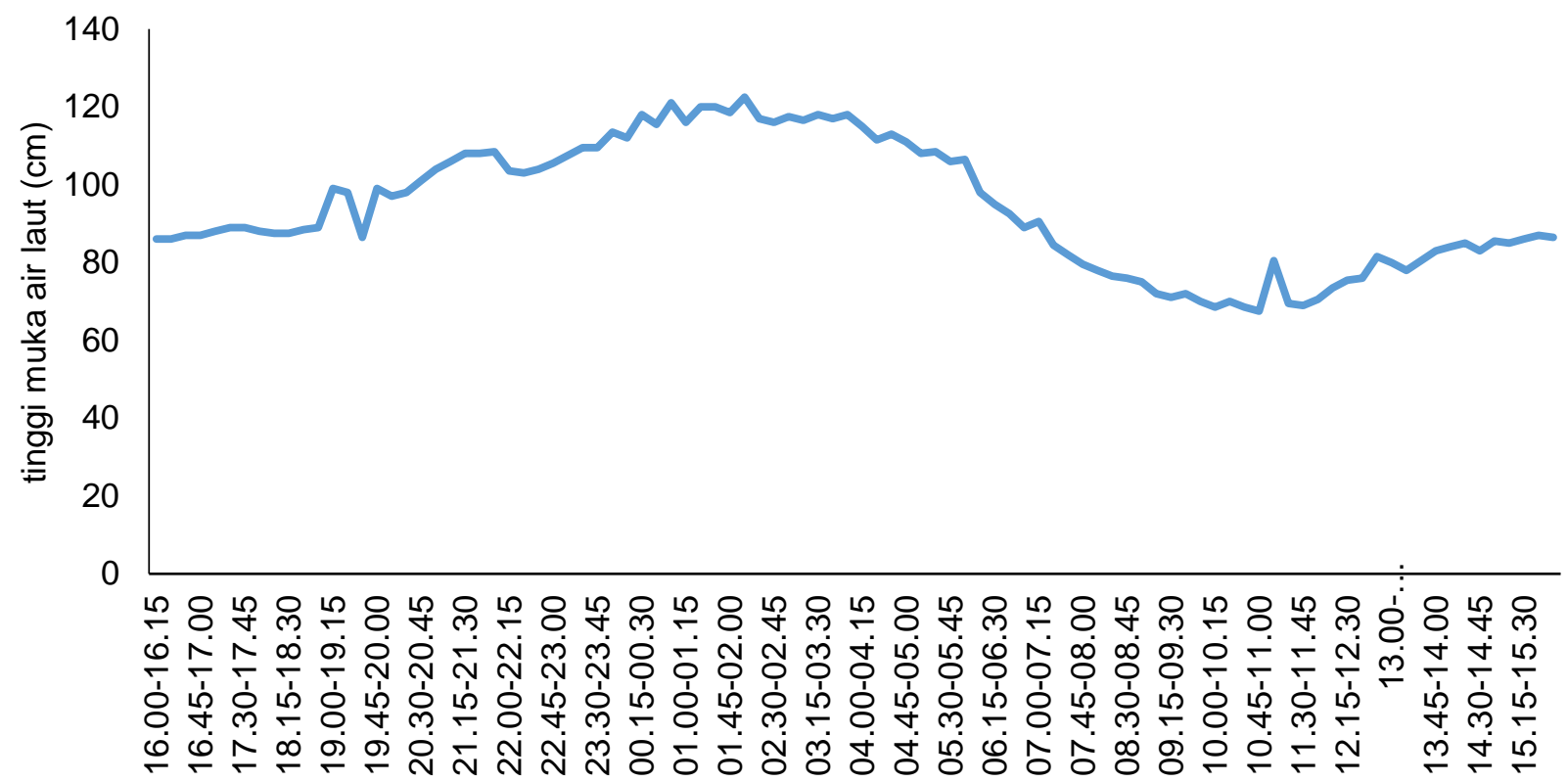

Gambar 2. Grafik Pasang Surut di Perairan Teluk Awur Pada Bulan Oktober 2019 Sumber BMKG Semarang 2019 
Pada penelitian ini, pergerakan air tertinggi saat pasang mencapai $1,25 \mathrm{~m}$ sedangkan pada saat surut terendah mencapai $0,63 \mathrm{~m}$ dengan kisaran pasang surut mencapai $0,94 \mathrm{~m}$. Selanjutnya tipe pasang surut air laut di Teluk Awur tergolong pasang surut tipe mixed tide prevailing semi diurnal, yaitu terjadi pasang surut terjadi dua kali dalam satu hari, interval tetap tinggi dan berbeda surut campuran condong keharian ganda sehingga dapat dikatakan bahwa masuknya sampah ke perairan Teluk Awur terjadi dua kali dalam sehari. Hal ini sesuai dengan pernyataan Potemra (2012) bahwa pasang surut dapat mempengaruhi pola penyebaran nutrien dan pengangkutan nutrien yang berasal dari darat ke perairan luas. Surut yang terjadi telalu rendah mengakibatkan padang lamun kekeringan dan menyebabkan kematian akibat terekspos sinar matahari langsung, selain itu akibat dari surut yang terlalu rendah menyebabkan muka air laut tidak menutupi padang lamun lagi. Hal ini banyak ditemukan di Stasiun 1 lokasi penelitian, kondisi ini dapat mempengaruhi kehidupan lamun di periaran Teluk Awur. Adapun jenis-jenis sampah anorganik yang ditemukan di lokasi pengambilan data di Teluk Awur Jepara disajikan pada (Tabel 5).

Sampah yang ditemukan pada daerah pesisir pantai merupakan sampah hasil dari buangan masyarakat yang masuk ke perairan seiring dengan siklus pasang surut yang terjadi. Sampah sulit terurai yang di temukan pada sekitar maupun perairan Teluk Awur antara lain: kaca, kain (piring kaca, botol kaca), plastik (botol plastik, snack, jaring ikan), karet, besi, dan seng. Jenis sampah anorganik yang paling banyak dijumpai merupakan karet, kain, kaca dan plastik (karpet, karung, kemasan snack). Kurangnya sampah dengan jenis besi dan seng diduga masyarakat daerah sekitar sering mengumpulkan sampah besi seng untuk kemudian dijual. Grafik tentang ukuran sampah yang ditemukan pada lokasi pengambilan data di Teluk AwurJepara disajikan pada (Gambar 3 ).

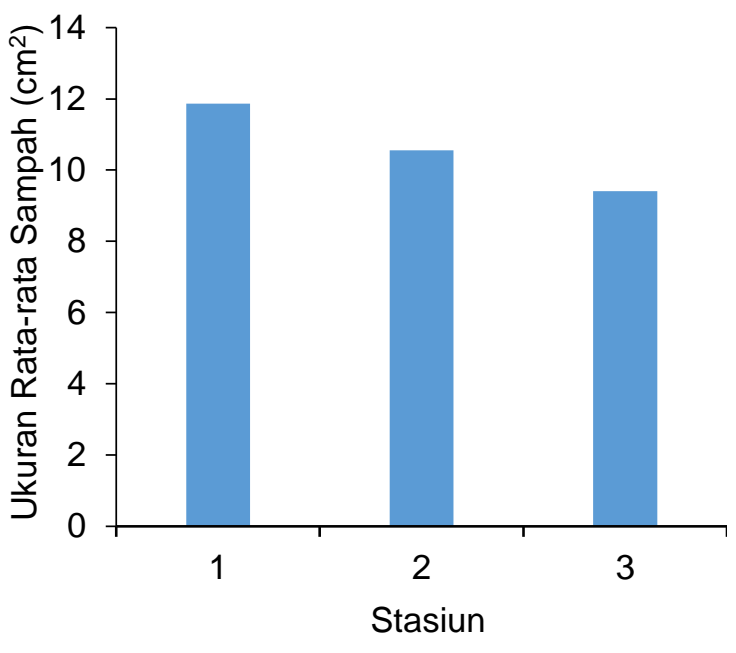

Pantai

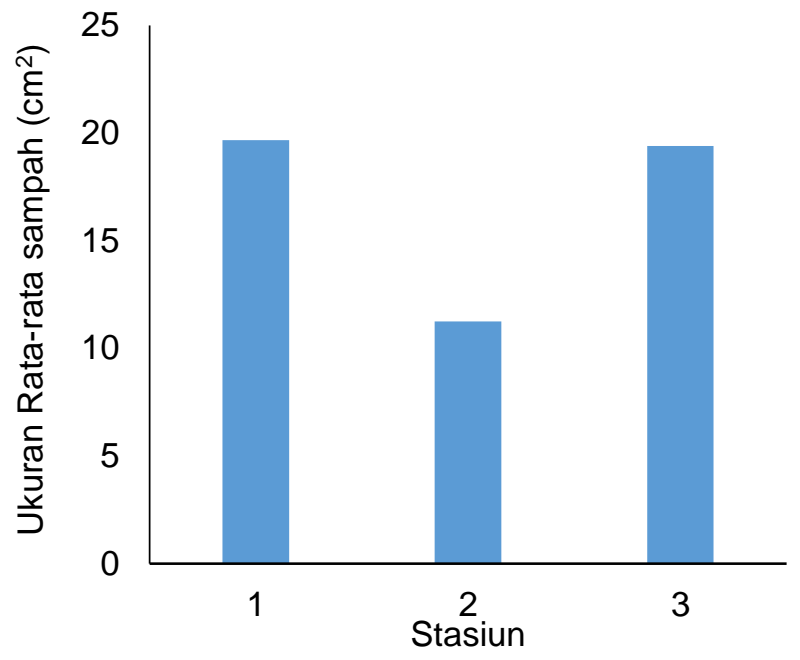

Padang Lamun

Gambar 3. Diagram Ukuran Sampah Setiap Stasiun di Pantai dan di padang lamun Pada Perairan Teluk Awur

Tabel 5. Jenis Sampah Yang di Temukan Pada Setiap Stasiun di Perairan Teluk Awur

\begin{tabular}{ccc}
\hline Stasiun & Jenis sampah di pantai & Jenis sampah di Padang Lamun \\
\hline 1 & Plastik & Plastik \\
2 & Kain & Plastik \\
& Plastik & Tali jaring \\
3 & Plastik & Plastik \\
& Busa & Tali Jaring \\
& Kain & Botol Plastik \\
\hline
\end{tabular}


Berat sampah yang ditemukan di lokasi penelitian di Teluk Awur Jepara disajikan (Gambar 4). Sampah yang ditemukan di setiap stasiun pengamatan memiliki ukuran rata-rata yang berbedabeda. Pengukuran sampah ini menggunakan metode $C$-siro dimana ukuran sampah telah dikategorikan dengan nilai pengelompokan (Schuyler et al., 2018). Berat sampah bervariasi di setiap stasiun pengamatan. Hal ini sesuai dengan pernyataan Ribic et al. (2012) proses pasang dan surut akan membawa masuk sampah dengan jumlah yang besar ke perairan.

Ketika sampah sampai di laut, sampah akan tenggelam dan tertumpuk di lokasi sampah pertama kali masuk ke laut (Galgani et al., 2000; Barnes et al., 2010). Tetapi, ada kemungkinan sampah mengapung di laut pada waktu yang lama sehingga bisa dijumpai jauh dari tempat asalnya . Sampah yang masuk ke perairan tidak semuanya akan terperangkap oleh padang lamun yang ada di perairan, dan juga tidak semua sampah yang telah terperangkap akan menetap di padang lamun melainkan ada juga yang akan menuju keperairan yang lebih dalam dikarenakan adanya peristiwa pasang surut. Hal ini sesuai dengan pengamatan yang telah dilakukan pada saat pengambilan data dimana sampel sampah laut yang terperangkap pada padang lamun yang ada di Stasiun 1 pada saat pasang sampah menghilang. Namun ada sampel sampah yang tetap berada di padang lamun pada saat pasang dikarenakan sampah tersebut telah banyak ditutupi oleh sedimentasi perairan dan berada di dekat substrat padang lamun.

Tentunya distribusi dari sampah yang ada di sekitar perairan Teluk Awur bergantung pada kondisi oseanografi yang ada. Pasang surut, arus, dan gelombang tidak hanya akan mengangkut nutrient dari daratan ke laut tetapi juga akan mengangkut sampah-sampah yang ada di sekitar perairan yang disebabkan oleh pencemaran sampah plastik yang terjadi di lokasi penelitian. Sampah ini akan masuk ke perairan dan akan melalui padang lamun, ada beberapa sampah yang terperangkap di padang lamun. Hal ini ditemukan di beberapa titik lokasi penelitian. Pengaruh yang terjadi akibat sampah plastik, hasil pengamatan yang dilakukan adalah perubahan pada morfologi daun lamun. Banyak daun lamun akan menjadi melengkung, daun berubah menjadi sedikit kekuningan diduga dikarenakan penetrasi cahaya sinar matahari kurang terserap daun lamun karena tertutupi sampah plastik. Tetapi hal tersebut berpotensi kecil mengakibatkan kematian pada padang lamun.

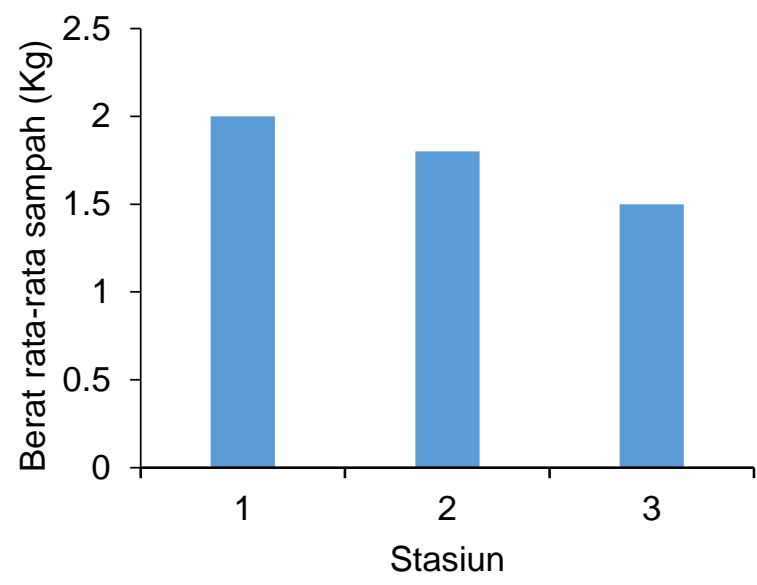

Pantai

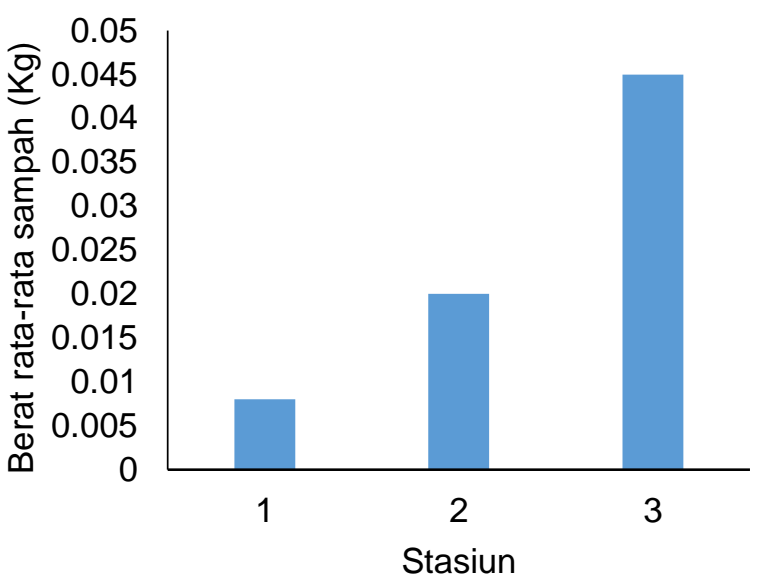

Padang Lamun

Gambar 4. Diagram Berat Sampah Setiap Stasiun Di Pantai dan Di padang lamun Pada Perairan Teluk Awur

\section{KESIMPULAN}

Kondisi parameter perairan sangat mempengaruhi kondisi padang lamun di Teluk Awur. Kondisi padang lamun di lokasi penelitian dikategorikan dalam kondisi tidak sehat, dikarenakan rendahnya nilai prosentase penutupan lamun (>25\%). Sampah plastik yang ada diperairan tersebut belum mengakibatkan kondisi buruk pada padang lamun, namun perlu waspada agar sampah makro 
plastik tidak semakin bertambah, yang dikhawitrkan apabila berlangsung terus menerus dapat menurunkan kondisi padang lamun. Penggunaan plastik harus dikurangi dengan mengganti bahan yang mudah teraurai dalam suatu produk atau sautu aktivitas.

\section{DAFTAR PUSTAKA}

Akib, A., Magdalena, L., Ambeng, \& Muhtadin, A. 2015. Kelayakan Kualitas Air Untuk Kawasan Budidaya Eucheuma cottoni Berdasarkan Aspek Fisika, Kimia dan Biologi di Kabupaten Kepulauan Selayar. Jurnal Pesisir dan Laut Tropis. 3(1):25-36.

Barnes, D. K., Galgani, F., Thompson, R. C., \& Barlaz, M. 2009. Accumulation and fragmentation of plastic debris in global environments. Philosophical Transactions of the Royal Society B: Biological Sciences, 364(1526):1985-1998.

Baron,C., Middelburg, J.J. \& Duarte, C.M. 2006. Phytoplankton Trapped within Seagrass (Posidonia oceanica) Sediments are a Nitrogen Source: An In Situ Isotope Labeling Experiment Limnology and Oceanography, 51(4):1648-1653.

Dahuri, R., Rais J., Ginting, S.P. \& Sitepu, M.J. 2001. Pengelolaan Sumber Daya Wilayah Pesisir dan Laut secara Terpadu. PT Pradaya Paramithah. Jakarta.

EI Shaffai, A. 2011. Field to seagrasses of the Red Sea. First Edition. Gland, Switzerland: IUCN and Courbevoie, France: Total Foundation. Viii + 56pp.

Jambeck, J. R., Geyer, R., Wilcox, C., Siegler, T. R., Perryman, M., Andrady, A., \& Law, K.L. 2015. Plastic waste inputs from land into the ocean. Science, 347(6223):768-771.

Mason, C.F. 1981. Biology of Freshwater Pollution. Longman. New York.

Nikki, M., 2009. Marine Litter: A Global Challenge. Nairobi: UNEP. 232 pp.

Patty, S.I., 2013. Distribusi Suhu, Salinitas dan Oksigen Terlarut di Perairan Kema, Sulawesi Utara. Jurnal IImiah Platax. 1:(3):148-157. Doi: 10.35800/jip.1.3.2013.2580

Potemra, J.T. 2012. Numerical Modeling with Application to Tracking Marine Debris Numerical. Marine Polution Bulletin 65(1-3):42-50

Rahmawati, S., Andri, I., Indarto, H.P. \& Azkab, M.H. 2014. Panduan Monitoring Padang Lamun. COREMAP CTI LIPI.Jakarta.Viii+37pp.

Ribic, C.A., Sheavly, S.B., Rugg, D.J. \& Erdmann, E.S., 2012. Trends in marine debris along the U.S. Pacific Coast and Hawai'i 1998-2007. Marine Pollution Bulletin. 64:994-1004.

Riniatsih, I. 2016. Distribusi Jenis Lamun Dihubungkan dengan Sebaran Nutrien Perairan di Padang Lamun Teluk Awur Jepara. Jurnal Tropis Kelautan. 19(2):101-107.

Riniatsih, I., Hartati, R., Endrawati, H., Mahendrajaya, R.T., Redjeki, S., \& Widianingsih. 2017. The application of Environmental Friendly Technique For Seagrass Transplantation. IOP Publishing. 116(1):012103.

Rustam, A., Kepel, T.L., Kusumaningtyas, M.A., Ati, R.N.A., Daulat, A., Suryono, D.D., Sudirman, N., Rahayu, Y.P., Mangindaan, P., Heriati, A., \& Hutahaean, A.A. 2015. Ekosistem Lamun sebagai Bioindikator Lingkungan di P. Lembeh, Bitung, Sulawesi Utara. Jurnal Biologi Indonesia. 1(2):233-241. Doi: 10.14203/jbi.v11i2.2197

Satria, N.M.K. \& Misbah, M.N. 2012. Analisis Pengaruh Salinitas dan Suhu Air laut Terhadap Laju Korosi Baja A36 Pada Pengelasan SMAW. Jurnal Teknik ITS. 1(1):G75-G77

Schuyler, Q., Hardesty, B.D., Lawson, T.J., Opie, K., \& Wilcox, C. 2018. Economic incentives reduce plastic inputs to the ocean. Marine Policy, 96:250-255..

Suparjo, M.T., 2009. Kondisi Pencemaran Sungai Babon Semarang. Kondisi pencemaran perairan sungai Babon semarang. Saintek Perikanan: Indonesian Journal of Fisheries Science and Technology, 4(2):38-45. Doi: 10.14710/ijfst.4.2.38-45 
Tangke, U. 2010. Ekosistem padang lamun (manfaat, fungsi dan rehabilitasi). Agrikan: Jurnal Agribisnis Perikanan, 3(1):9-29. Doi: 10.29239/j.agrikan.3.1.9-29

Waycott, M., McMahoon, Mellors, J., Calladine, A. \& Kleine, D. 2004. A Guide to Tropical Seagrasses of the Indo-West Pacific. James cook University, Townsville Queensland Australia. 